\title{
Research on Improving the Training Quality of Undergraduate Communists in Independent Colleges
}

\author{
—— Taking Beijing Normal University. Zhuhai for Example
}

\author{
Jiang Lina \\ Beijing Normal University. Zhuhai, Zhuhai Guangdong 519087
}

\begin{abstract}
Problems which undergraduate communists have in their motivations, ideal and faith to be members of Chinese Communist Party attach new trend and situation to the education and cultivation of undergraduate communists. The author has surveyed students of 14 departments in Beijing Normal University Zhuhai Campus. The questionnaire which is to learn the problems faced in the recruiting, cultivation and education of undergraduate communists, mainly concentrates on 5 aspects - motivations to be a party member, requirements for a party member, activities in students' party branches, education of communists and recruiting of party members. At last, based on the analysis of the results and according to different groups, Beijing Normal University Zhuhai Campus, as an independent college, carries on multi-level party classes, delegates the authority of party class teaching and adopts popular mode of party classes. At the same time, she combines the classes with social work, enhances the evaluating work of party members and arouses the awareness of undergraduate communists, and also promotes the training quality of undergraduate communists.
\end{abstract}

Keywords: independent colleges; undergraduate communist; Party classes; training quality

\section{Introduction}

As the university students is one of the most promising groups, cultivation and recruiting of party members among them is not only an important resource for Chinese Communist Party, but also an approach for our party to choose, cultivate talents for our party's work. It is important and significant to have a correct understanding of the problems faced in the cultivation and development of undergraduate communists, strengthen researches on the cultivation mode of outstanding undergraduate communists and explore approaches to select, recruit and cultivate outstanding party members. According to the statistics from CCCPC (Central Committee of the Communist Party of China), at the end of 2011, the number of members of Communist Party of China has reached 82,602,000, which has exceeded the gross population of Britain and France and is approximately equal to the gross population of Germany. ${ }^{[1]}$ As of June 30, 2011, there are $3,058,000$ undergraduate communists in regular colleges which accounts for $13.2 \%$ of the total number of students. Every year, the number of fresh undergraduate communists in Guangdong accounts for more than $40 \%$ of the total number of new party members. And 88,100 undergraduate communists were recruited in 2011 in Guangdong province, which accounts for about $44 \%$ of the total number of fresh party members. ${ }^{[2]}$

Recent years, colleges and universities attach more importance on recruiting party members among college students, which propels the work of party building among college students to a favorable trend. However, it is undeniable that education and cultivation of undergraduate communists are facing new trend and situation - part of undergraduate communists have problems in their motivations, ideal and faith to be members of Chinese Communist Party.

\section{The Present State of Cultivation and Recruiting of Student Party Members and Statistics Analysis}

\subsection{The Survey of Basic Information}

The author has surveyed students of 14 departments in Beijing Normal University Zhuhai Campus and 500 questionnaires were put out. The questionnaire is mainly made in 5 aspects - motivations to be a party member, requirements for a party member, activities in students' party branches, education of communists and recruiting of party members, to learn the problems which are faced in the process of recruiting and cultivation of student party members. There were 429 valid questionnaires and the valid returned rate reached $85.5 \%$. The result has been showed in Table 1 .

\subsection{Problems Lurking in Recruiting of Student Party Members}


Table 1. The Result of Survey on Student Party Members

\begin{tabular}{|c|l|c|c|}
\hline \multirow{2}{*}{ Gender } & Male & 190 & $44 \%$ \\
\cline { 2 - 4 } & Female & 239 & $56 \%$ \\
\hline \multirow{3}{*}{ Social Identity } & Activists & 225 & $52 \%$ \\
\cline { 2 - 4 } & Probationary Members & 124 & $29 \%$ \\
\cline { 2 - 4 } & Full Members & 80 & $19 \%$ \\
\hline \multirow{3}{*}{ Native Place } & Provincial Capitals and Municipalities & 91 & $21 \%$ \\
\cline { 2 - 4 } & Counties and Cities & 228 & $53 \%$ \\
\cline { 2 - 4 } & Villages and Towns & 110 & $26 \%$ \\
\hline
\end{tabular}

\subsubsection{The Diversification of Students' Motivations to be Party Members, Most Students Having Positive Attitude to be Party Members}

It is showed that $18 \%$ of students join the Party to hunt for good jobs, $4.8 \%$ of them just follow the trend, while $12.8 \%$ of them comply with their parents' request. Meanwhile, $64.1 \%$ of the students join the Party for agreeing with our party's tenets. Hence, although students' motivations to join the party are diverse, most of them join our party for agreeing with our party's tenets. Whether the diversification of students' motivations to be party members means students' selfish and utilitarian aims? Of course not! During new democratic revolution period, farmers actively participated in revolutions with aims to living better lives, then they joined our party to be fighters for communism and struggled in revolutions. Can we hold the views that these farmers who joined our party are selfish and utilitarian? Hence, it is important for students to gradually correct motivations to be party members by taking Party classes. According to statistics, $4 \%$ of the students don't care to be party members, $94.4 \%$ of them have positive attitudes, while $1.6 \%$ of them don't have active attitudes. Based on analysis of reasons why they are reluctant to join the Party, 55.2\% of the students think that they don't have a comprehensive understanding on the Party, $31.5 \%$ of them hold the views that too much formalistic work after joining the Party will have an effect on their study, $9.5 \%$ of the students tell the lack of the Party members' leading roles, and $3.8 \%$ of them choose other reasons. In the survey on approaches for students to know our party, $28.7 \%$ of the students learn from their family members, and $33.6 \%$ of them know from their teachers. $12.1 \%$ of the students know from their classmates, $52 \%$ of them learn from Internet, TV and other media and $22.6 \%$ of them have a basic knowledge of our Party by reading books.

\subsubsection{The Low Quality of Student Party Members and the Lack of their Leading Roles}

According to the questionnaires, only $24.7 \%$ of students think that student communists around them play leading roles, while $62.2 \%$ of them hold the views that student communists play leading roles, but not obvious, and $13.2 \%$ of them think that they have no influence on them; $19.8 \%$ of the students think that the students communists around them lack possessiveness, $17.5 \%$ of them think that their classmates who join the Party seem hard to get along with, $55.2 \%$ of them hold the views that their student communists lack appeal, and $7.5 \%$ of them choose other reasons. As for problems which probationary Party members have, $34.5 \%$ of the students think that some probationary Party members have inferior sense of principle, $40.9 \%$ of the students hold the views that these probationary Party members are inactive to group activities, $38 \%$ of them think that they cannot play a role at the crucial moment. How to deal with the situation where a party member or a probationary party member cannot play a leading role (multiple choices)? $70 \%$ of the students think that they should be criticized, and $8.6 \%$ of the students hold the views that there is no need to deal with. $40.8 \%$ of the students think that the probationary period of the probationary party members should be extended or disqualified, and $33.1 \%$ of the students think that materials of democratic appraisal of full members of the Party should be kept to membership files.

\subsubsection{The Single Form of Activities in Party Branch and the Content of these Activities Lacking New Ideas}

According to the analysis of these questionnaires, $37.3 \%$ of the students frequently participate in activities of the Party Branch, $32.6 \%$ of the students participate in these activities occasionally, and $16.3 \%$ of them seldom participate in these activities and $13.8 \%$ of them barely participate in these activities. While, $38.7 \%$ of the students think that their classmates who have join our Party have an active attitude towards activities of the Party Branch, $49.4 \%$ of them hold the views that their classmates' participation in these activities for the requirement of discipline in the Party, $8.2 \%$ of them think that whether participate in these activities or not doesn't matter, and $3.7 \%$ of the students think that there are still a few student communists who are frequently absent from these activities without reasonable causes. As for the reason why student party members are inactive in activities which are conducted by our Party(multiple choice), $60.8 \%$ of the students attribute this result to the single form of these activities, $72.2 \%$ of the students attribute this phenomenon to the lack of new ideas in these activities. $40.6 \%$ of the students think that the unsatisfactory result of these activities matters a lot, $30.5 \%$ of them attribute the result to the less-advanced approach which these activities adopt, and $20.7 \%$ of the students hold the views that the expenditure is not enough to support these activities. As for the most favorable form of activities of the Party Branch for the students, $11.1 \%$ of them vote for 
meetings of democratic life, $50.1 \%$ of them favor the voluntary service, $3.7 \%$ of them prefer the study of theories, and $34.9 \%$ of them side with visit to the educational base of Patriotism.

\subsubsection{The Repetition of the Content of the Party Classes and the Knowledge which the Party Members have Learned, and the Weakness in Practice}

According to the analysis of these questionnaires, as probationary Party members, what kind of knowledge which is related to our Party they have learned (multiple choice)? $77.1 \%$ of these probationary Party members have a good knowledge of our Party's history, 54\% of them have learnt Party Constitution, and $15.6 \%$ of them know the organizational system and organs of the Party, while $60 \%$ of them know the requirements and procedures to be full member of the Party, $5.1 \%$ of them have learnt the rights and duties of the Party members', $62.7 \%$ of these Party members know the qualities, tenets and guiding concepts of our Party, and $42.1 \%$ of them have a good knowledge of the system and regulations of the Party. As for the knowledge which should be enhanced for these student Party members (multiple choice), $35 \%$ of them pay more attention to the history of our Party, $36 \%$ of them attach great importance to the learning of the Party Constitution, $36.1 \%$ of them think that we should enhance the learning of the organizational system and organs of our party, $63.2 \%$ of them hold the views that we should arouse the awareness of the requirements and procedures to be full members, $5.8 \%$ of them think that we should learn more about the rights and duties for Party members, $32.1 \%$ of them think that we should strengthen our knowledge on the qualities, tenets and guiding concepts of our Party, $43.5 \%$ of them think that we should reinforce their awareness of the system and regulations of the Party, and $24.5 \%$ of them think that the analysis of the current political affairs is more important. As for the opinions on the 4-hour-class of the Party, $71.1 \%$ of the students think that it is necessary, $25.9 \%$ of them don't care much, while $9.3 \%$ of them think that there is no need. On the form of the Party classes, $55.7 \%$ of the student Party members favor visits to the educational bases of Patriotism, $63.3 \%$ of them prefer films and records on patriotism, $60.6 \%$ of them choose to combine the practice with the learning of service and participate in service for classmates and communities, and $61.3 \%$ of them choose to take part in voluntary service.

\section{Practice and Exploration on Promoting the Training Quality of Undergraduate Communists in Beijing Normal University Zhuhai Campus}

Focusing on the Party classes, Beijing Normal University Zhuhai Campus combines hierarchical classroom study, after-class classification practice, and centralized classroom education with after-class organizational review to promote the training quality of these undergraduate communists by institutional innovation in a focused and effective manner.

\subsection{Aiming at Different Groups, Carrying out Multi-level Party Class Teaching}

We can divide the Party class to 3 levels - training classes of applicants for Party membership (hereafter referred to as training class), workshops for probationary Party members (hereafter referred to as workshop), and advanced classes for backbone of the Party members (hereafter referred to as advanced classes). There are different key points in different level of classes. The training classes aim to train those students who apply to join our Party, help them know the basic knowledge of the Party and strengthen their faith to be full Party members. Anyone who has applied for Party membership can take the classes through voluntary application. The training class will be held at least one time per term, and will meet the demand for recruiting of the Party members. The basic work of these workshops is to continuously educate probationary Party members and widen their scope of knowledge. They hope to cultivate Party members' ability to analyze independently and strengthen their Party spirit. The workshop will be hold one time per term and all the probationary Party members should take the course. The advanced classes aim to promote the theoretical level, working ability and self-qualities of the backbone of student Party members. Multi-level Party class teaching can meet different demands of Party members who have different level of knowledge on our Party. Every probationary Party member will have 2 or 3 training class before they officially join the Party. Targeted training classes can effectively solve these problems which have been showed in questionnaires and make the Party classes more effective.

\subsection{Distributing the Authority of the Party Class Teaching to General Party Branch of Basic Level and Teaching in Small Classes}

It is less effective to teach the Party classes in large-scale classes and it is roughly the same with the problems showed in questionnaires. Based on the survey, we gradually reform and distribute the authority of Party class teaching to the General Party Branches at every grassroots level. This kind of reform is conducive to the combination of the Party classes with practice and also the participation of the students. Hence, many student party branches have organized various kinds of activities to help these students who apply to join our Party promote their spiritual level through the combination of the theories and practice. Compared with giving large-scale classes, because of many students have elective courses on weekends which will arise schedule conflicts; it is more convenient for these General Party Branches to arrange their Party classes independently. The flexible class arrangement of every department can help students select their class at their will. Every department can also combine the Party classes with student work depending on the features of students' majors. For instance, the topic of School of Education is Emotion, Cognition and Belief-how can I strive to join the Party and be a Qualified Party Member, School of Logistics talks about Strengthen your Belief-College 
Students and Chinese Communist Party, and School of Information Technology focuses on the Advancement of the Communists and Chinese Traditional Virtues. Every department not only provides students with wonderful Party lectures, but also gives them opportunities to put theories into practice. Students of Party class in School of Information Technology have been arranged to pay a visit to Sun Yat-sen's Former Residence, International Business Studies has held activity of Red Films Week, the student Party Branch in School of Management organized students to participate in rural voluntary labor in communities, while School of Logistics and School of Law and Politics have also held related activities. Students have actively participated in these activities and most of them can seriously learn from these lectures and actively participate in social practice activities. Students think that they have gained systematic and comprehensive understanding of basic knowledge and theories of our Party through Party classes. And they have also had a better understanding of the Party and their emotion towards our Party has been enhanced.

\subsection{Enriching the Forms of Party Classes, and Making Party Classes More Popular}

Advanced class of the Party firstly tries to reform to solve the problem of single form of the Party class and the lack of attraction to students. It carries out "Colorful Party Class-My Chinese Dream", and gives courses on topics of "Orange Power", "Red Poem", "Green Belief", "Blue Classics" and "Golden Glory". There are 210 leading Party members from 14 departments in advanced class and they are divided into 12 groups. Taking class of "Golden Glory" for example, firstly, these 12 groups shared their achievements in the past week. And each group also made a thorough explanation on how to have a comprehensive understanding of the content of the Party classes by this new mode of learning, and elaborated the new form of the Party class and the roles which these leading Party members have played, then they give advice on how to actively participate in the construction and management of the college. At the same time, the second group came up with an idea which tried to make the Party members closer by SMS Party class, and this idea helped them win classmates' recognition. In the following part- "Hot Issues Quiz" which is related to the history of our Party and composed of "Required Questions", "Lightning Round", "Quick Fire Round", "Red Songfest", and "Risking Round". Each group intensively and enthusiastically prepared for this part which knitted a tense atmosphere. In "Lightning Round", the host quickly spoke out the question, and each group should choose a representative to quickly make a judgment in 90 seconds. Desire for the winner made all of the groups stress out.

With the solid knowledge of Party construction and sensitive ability of listening, the seventh group won top score in this part. And the calm and cool attitude showed by members of the eighth group impressed all the students. While in "Quick Fire Round", all members tried their best to win honor for their own groups. In the following round, all members in all groups answered too quickly to divide the sides, which made the staff rack their brain to come up with new rounds-Quick Fire while Blowing Balloons" and "Quick Fire while Making Phone Calls" - to decide a winner. All of the students enjoyed the harmonious atmosphere in "Red Songfest", they not only correctly guessed the old red songs, but also enjoyed those beautiful voices.

Student Gao who registered in School of Sports and Leisure in 2012 told that she learnt a lot from the training class. She not only had a better understanding of the history of our Party, but also got a chance to communicate with students in other schools. She also told that she would cherish her life in college and played a leading role. Zhao xiaokun, the president of Xinhuo Club, as a member of this advanced class, he said, "In today's 'Q\&A Round', I find my weakness in the knowledge of our Party. This advanced class provides us with a chance to check and widen our scope of knowledge".

\subsection{Combining the Party class with Social Service and Put the Teaching of the Party Class into Practice}

"Combination of education with productive labor and social practice" and "combination of theoretical education and practical education" are the fundamental principle and basic approach of education. Participating in social practice, college students can not only learn more about the society and national condition, enhance their abilities and qualities, but also get the chance to have a better understanding on guidelines and policies of our Party. It is irreplaceable and significant for students' overall self-development. Service-learning is a method which pays the same attention to service and study, and it is also a form of social practice with special meaning. [3] Service-learning is the combination of service and study, namely, learning from the process of serving others. Service-learning connects colleges and universities with communities (society) which provides students with the chance to meet the needs of communities (society) by actively participating in community (social) service related to our courses and applying their knowledge and skills. The proposal of service-learning aims to promote students' knowledge, abilities and qualities through social service, and help them grow to be the ones with strong sense of social responsibility and enough abilities to serve the society in the process of caring about the society and others. Service-learning has the same significance with our Party's tenet - serving the people heart and soul.

Hence, it has been elaborated in Rules for Work of Student Party Classes in Beijing Normal University Zhuhai Campus, training classes should be composed of at least 8-class hour-theory learning class and 4-class hour-practice class. Workshops should have at least 2-class hour-theory class or 2-class hour-practice class. Various kinds of teaching forms can be adopted, such as centralized teaching, break-out sessions, thesis seminars, visiting and learning, having lectures, learning the spirit of the central documents, social surveys, paper writing, participating in voluntary work, social and community service and so on. Advanced classes should pay the 
same attention to theory learning and practice, and should be given for at least 4 class hours. The forms of teaching in advanced classes are centralized teaching, work experience exchange, researches on Party construction, investigating and surveying, taking temporary posts in or out of colleges and so on. And Student Affairs will provide with fund support.

\subsection{Strengthen the effect of Party Classes, Completing the Party members' appraisal and Enhancing Student Communists' Awareness}

Democratic appraisal on student Party members is an important step to enhance the awareness of the Party Members and promote the qualities of student Party members. It is an effective way to strengthen the recurrent education, management and supervision of student Party members by institutional construction. It also ensures that students' ideological and political education work can go smoothly. It provides with effective measures to solve problems of the lack of student Party members' leading roles and inconsistent performance before and after they join the Party which have been showed in these questionnaires. In practice, the Party members' appraisal further enhances both the effect of the Party classes and the awareness of student Party members', and it has been widely received.

\section{Conclusion}

With the emergence of the new trends and situations of the training and education of undergraduate communists, Beijing Normal University Zhuhai Campus propels the institutional construction through the Party classes construction in the process of promoting the student
Party members' qualities and has come up with a set of complete and perfect mechanism which is in line with its own actual situation and can help promote the qualities of the Party members. It adopts three-level cultivation mode for applicants of the Party membership, probationary Party members and the Party members, and reaps some fruits. It also carries out different level of the Party classes for applicants for Party membership, probationary Party members, official Party members and members of the Party Branch Committee. This kind of reform makes it easier for students to understand the content of these classes and also provides with evidence to exam their performance. However, it still remains to make more attempts on how to enhance their belief in communist ideal and play leading roles, and finally grow to be qualified and reliable successors of Socialism with Chinese Characteristics.

\section{Acknowledgements}

This paper is supported by the Project of Guangdong Party Construction Research Institute of 2012 (2012MBZZB13), and guided by Dai Wei, the head of this project.

\section{References}

[1] The total number of the Party member is $82,602,000$, while the number of the primary Party Organization is 4,027,000[J]. Research on Party Construction (July, 2012), 16.

[2] Wu Chunyan. How to Practice the Spirit of Student Probationary Party Members[N], Guanming Daily( 22 November, 2012) (6).

[3] Chen Yingfei. New Vision of Service-Learning Courses in Middle Schools, <Lu Ming>-E-paper of School of Literature in National Chung Hsing University (1 August, 2009)(17). 